\title{
空圧ステージに対するモデル追従制御の適用に関する一考察
}

武井 陸*1, 涌井 伸二*2

\section{A study of implementation of model following control for a pneumatic stage}

\author{
Riku TAKEI $^{* 1}$ and Shinji WAKUI ${ }^{* 2}$ \\ ${ }^{* 1}$ Graduate School of Engineering, Tokyo University of Agriculture and Technology \\ 2-24-16, Naka-cho, Koganei-shi, Tokyo 184-8588, Japan \\ ${ }^{* 2}$ Institute of Engineering, Tokyo University of Agriculture and Technology \\ 2-24-16, Naka-cho, Koganei-shi, Tokyo 184-8588, Japan
}

Received: 27 July 2016; Revised: 30 September 2016; Accepted: 1 December 2016

\begin{abstract}
This paper considers the performance improvement of pneumatic stage positioning. The pneumatic system, which consists of air cylinders, servo valves, and pipes supplying compressed air to a pneumatic stage, have parameter variation due to mainly air compressibility. It leads to low positioning repeatability. To compensate for this parameter variation, model following control (MFC) is employed for the pneumatic system. One of authors has previously shown the effectiveness of MFC. However, how to select desired model to follow and controller used for MFC (called "the model following controller") is not considered sufficiently. Then this paper considers appropriate model and the model following controller from the viewpoint of transfer function. As a result of considerations, it is found that the model cannot be selected freely, as represented by reference model of model matching two degrees-of-freedom control system, but rather should be just equal to the pneumatic system. Furthermore, it is also found that a PID controller is better than a PI as the model following controller so as to improve transient response of MFC. Validity of the proposed model and model following controller are presented by pole-zero loci and experimental results. The effectiveness of MFC with both proposed model and model following controller is shown by results of repeated positioning.
\end{abstract}

Key words : Model following control, Motion control, $\mathrm{PDD}^{2}$ control, Pneumatic equipment, Positioning

\section{1. 緒言}

空気圧シリンダは取扱いの簡単さ，安全性，そして低価格であるなどの利点から，各種生産現場で利用され ている。しかし，空圧系が持つ空気の圧縮性，摺動部の機械摩擦に起因する非線形要素により，正確な位置制 御は容易でない（橋本他，1991）（則次他，1994）。そのため, この利用は単純な往復運動が大半であり，半導 体露光装置のように，微小ストロークの繰り返し位置決めが要求される分野での応用は稀である. 現状では, 一部の半導体検査装置おいて応用され始めた程度に留まる.

空圧駆動系の位置決め制御に関する研究は，たとえば最適制御，ファジィ制御，外乱オブザーバなどこれま で多岐にわたって行われてきた（藤原他，1996）（Parnichkun and Ngaecharoenkul, 2001）（三東，涌井，2013）.

一方，文献（Kato et al., 2007）では，空圧式除振装置への供給空気の制御に使用するスプール形サーボバルブが 有する非線形の補償法として，モデル追従制御（Model following control: 以下，MFC と略記）が提案され，その 有効性が示されている. 同制御法では, 制御対象と設計者が指定するモデルの両出力の偏差をとり, 制御器（以 下, モデル追従制御器と呼称）を介して操作量に帰還するループ構造をとる. そして, モデル追従制御器によ り同偏差を零とすることで, 制御対象の出力をモデルのそれに追従させる手法である. 筆者らの一部は, MFC

No.16-00334 [DOI:10.1299/transjsme.16-00334], J-STAGE Advance Publication date: 15 December, 2016

${ }^{* 1}$ 学生員, 東京農工大学大学院工学府（下184-8588 東京都小金井市中町 2-24-16）

$*_{2}$ 正員, 東京農工大学大学院工学研究院

E-mail of corresponding author: s166787z@st.go.tuat.ac.jp 
を空圧ステージに対して適用することで, 空圧系固有の特性変動を補償し, 繰り返し位置決め精度の向上を達 成している (Ito et al., 2016). しかし，その際 MFC の緩慢な応答が確認されていた．ステージには速応性が求め られる.アウタループのハイゲイン化による高速位置決めを実現するためには，インナである MFC の高速化が 前提となる。

そこで本論文では，空圧ステージに対する MFC 適用時の留意点を示し，これを踏まえて改良を施す．具体的 に，モデル選定時における留意点を示す．まず，空圧系とは異なる特性をもつモデルを指定したとき，空圧系 の伝達関数より構造的にモデル追従が不可能であることを示す．つまり，モデルマッチング型 2 自由度制御系

（田中他，1999）における参照モデルのように，モデルは任意指定できるのではなく，空圧系に限りなく等し く設定しなければ追従しない. これに加えて, モデルの伝達関数の構造を空圧系のそれに一致させたうえで, パラメータを真值に接近させることにより，MFC が高速化するという定性的理解も得た．そのためには空圧系 の正確な同定を要するが，実際には同定誤差は避けられない．この誤差を補償するのがモデル追従制御器であ る. 文献（Kato et al., 2007）では，同制御器にPI 補償器を用いている。 しかし，同補償器の優位性までは明示 されておらず，モデル追従制御器の検討は不十分であった，そこで，系の動特性において支配的な低次元の項 より部分補償すべきとする部分的モデルマッチング（北森，1998）の観点に基づき，同制御器を比較・検討す る. その結果, PI より PID 補償器の方が高次項のマッチングが可能であり, より追従性が増すことがわかった.

本論文の構成は以下の通りである. 2 章では, 実験環境と制御構成について述べる. 次に, 3 章ではモデルの選 定，4章ではモデル追従制御器の検討を行う．5 章では, まず実験的にモデルを調整し, パラメータ誤差の低減 を図る. そして, 調整後のモデルに対して上述の PID 補償器を適用したときの有効性を実験結果より示寸. 最 後に, 6 章で結論を述べる.

\section{2. 空圧ステージと制御構成}

\section{$2 \cdot 1$ 空圧ステージ}

空圧ステージの外観を図 1 に示寸. 質量 $15 \mathrm{~kg}$ の同ステージは転がり軸受で案内され, 水平方向に $10 \mathrm{~cm}$ の可 動範囲を有する．同ステージを含む実験構成を図 2 に示寸．エアコンプレッサで生成された圧縮空気は，レギ ユレータを介してエアシリンダ（Airpel, M16D300.0S）へ両方向から供給される. 同シリンダはピストンで $2 つ$ のチャンバに区切られており，これら内部に充填された圧縮空気の圧力差がステージの駆動力となる．ステー ジ側面には差動変圧器 (Linear variable differential transformer: 以下, LVDT と略記) (SHINKO ELECTRIC, LT2-120R) が固定されており, これがステージ位置を検出する. また, 各チャンバ内には圧力センサ (Setra, Model 204）が備えられ，差圧検出回路を介して両チャンバの差圧を検出する. 検出された両信号はDSPにフィードバ ックされる. DSP においては, $2 \cdot 3$ 節にて後述する制御則に基づく演算が行われ，各サーボバルブ（LINATOR, EWS 3/4) へ操作量を送る. バルブは印加電圧に応じて開閉し, エアシリンダへ流入する空気の流量を制御する. その結果生じるチャンバ間の差圧により, ステージは駆動される.

\section{$2 \cdot 2$ モデル追従制御}

図 3 に MFC のブロック図を示す.ここで, $P(s)$ : 空圧系, $P_{m}(s)$ : モデル, $C(s)$ : モデル追従制御器, $K_{\text {pres }}$ : 圧 力センサ感度 $[\mathrm{V} / \mathrm{Pa}], W^{\prime}(s)$ : 操作量 $[\mathrm{V}], P_{d}(s)$ : 空圧系の出力である圧力 $[\mathrm{Pa}], E_{M F}(s)$ : 偏差 $[\mathrm{V}]$ である. 同制御法

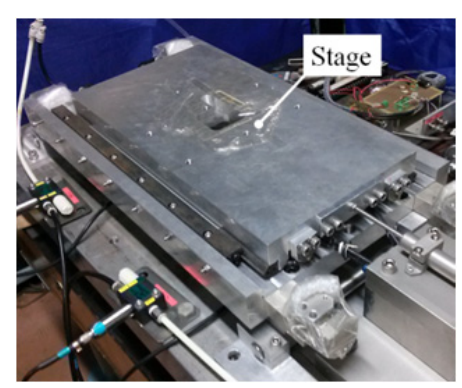

Fig.1 Pneumatic stage.

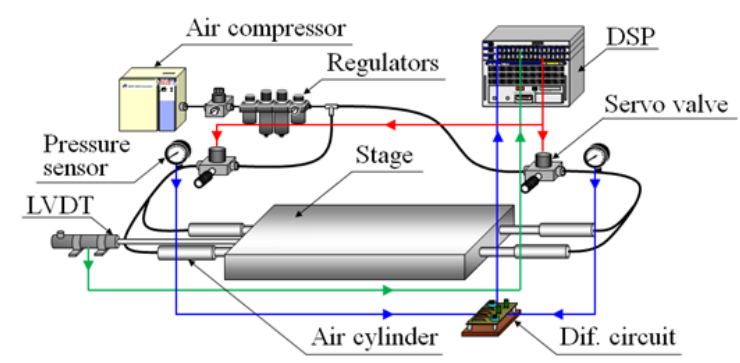

Fig. 2 Experimental setup.

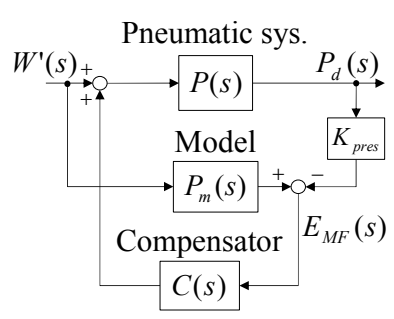

Fig.3 MFC. 
は， $P(s)$ の出力を $P_{m}(s)$ のそれに追従させる手法である.図 3 より，

$$
E_{M F}(s)=P_{m}(s) W^{\prime}(s)-K_{\text {pres }} P_{d}(s)
$$

の関係が得られる。モデル追従制御器 $C(s)$ により偏差 $E_{M F}(s)$ が零となるとき，式(1)は,

$$
\frac{K_{\text {pres }} P_{d}(s)}{W^{\prime}(s)}=P_{m}(s)
$$

となり, 空圧系 $P(s)$ の特性はモデル $P_{m}(s)$ に等しくなる. 空圧系 $P(s)$ は圧縮空気を供給する配管, エアシリンダ, そしてサーボバルブから構成される。これらは空気の圧縮性による非線形性を有するため, 特性に摇らぎをも

つ. そのため, 繰り返し位置決めの際，ステージ位置にばらつきが生じる．これを補償するために，空圧系に 対して MFC を適用する. ここで, モデル $P_{m}(s)$ は設計者が指定する. モデルの適切な選定方法については 3 章 で詳述する，次節では，MFCを含めた空圧ステージの制御構成について述べる.

\section{$2 \cdot 3$ 制御構成}

空圧ステージの制御構成を図 4 に，パラメータの定義を表 1 に示す.まず，同図の赤線部を除く基本構成か ら説明する. 空圧ステージは，空圧系と機械系から構成される．前者は配管での損失分を考慮して 1 次遅れ系，

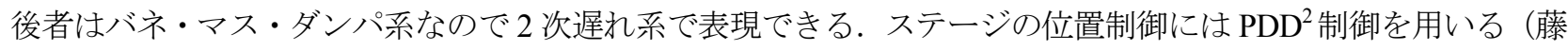
田他，2006）（柳川，涌井，2010）。ここで，空圧系前段の PI 補償器（図中，Pre-PI）により，空圧系を積分特性 にする. 具体的には, Pre-PI と空圧系の両時定数を一致させることで極零相殺を発生させている. このとき，目 標值 $R(s)$ から位置 $X(s)$ までの伝達関数は次式である.ただし, $\mathrm{PDD}^{2}$ 制御の擬似微分器を完全微分器としている.

$$
\frac{X(s)}{R(s)}=\frac{K_{p} K_{a i r} A_{0}}{T_{a i r} s\left\{M s^{2}+\left(D+\frac{K_{d d} K_{a i r} K_{p o s} A_{0}}{T_{\text {air }}}\right) s+\left(K+\frac{K_{d} K_{a i r} K_{p o s} A_{0}}{T_{\text {air }}}\right)\right\}+K_{p} K_{a i r} K_{p o s} A_{0}}
$$

式(3)分母において，剛性項に $K_{d}$ ，粘性項に $K_{d d}$ が含まれている，そのため，これらゲインの調整によりステー ジの岡性および粘性の操作，具体的には，ステージの残留振動の周期短縮およびオーバシュートの抑圧ができ る. そして, 図 4 の赤線部が MFC に該当する箇所である. モデルは空圧系と同じ 1 次遅れ系に設定している. MFC 適用時，Pre-PI と極零相殺させるためである。モデル追従制御器には文献（Kato et al., 2007）と同様に，PI 補償器（図中, Model-PI) を実装している.ただし，後の 4 章において，ループのハイゲイン化の意味で適切な モデル追従制御器の検討を行い，この結果を踏まえて変更する. なお，圧力センサ出力の高周波ノイズカット のため, Model-PI 前段に遮断周波数 $100 \mathrm{~Hz}$ のローパスフィルタ（図中，LPF）を設置している.

Table 1 Parameters of control system for the pneumatic stage.

\begin{tabular}{clc|clc}
\hline \hline Symbol & & Unit & Symbol & & Description \\
\hline$M$ & Mass of the stage & $\mathrm{kg}$ & $K_{v}$ & Gain of the model \\
$D$ & Viscous damping coefficient of the stage & $\mathrm{N} \cdot \mathrm{s} / \mathrm{m}$ & $T_{m}$ & Time constant of the model \\
$K$ & Spring constant of the stage & $\mathrm{N} / \mathrm{m}$ & $K_{p r e s}$ & Sensitivity of the pressusre sensor \\
$A_{0}$ & Piston area & $\mathrm{m}^{2}$ & $T_{l p f}$ & Time constant of the low pass filter \\
$K_{p}$ & Proportional gain of the PDD ${ }^{2}$ controller & $\mathrm{V} / \mathrm{V}$ & $K_{m p}$ & Proportional gain of the model PI compensator \\
$K_{d}$ & Differentiation gain of the PDD $\mathrm{PD}^{2}$ controller & $\mathrm{V} / \mathrm{V}$ & $K_{m i}$ & Integral gain of the model PI compensator \\
$K_{d d}$ & Second order differentiation gain of the PDD ${ }^{2}$ controller & $\mathrm{V} / \mathrm{V}$ & $r$ & Reference \\
$T_{d}$ & Time constant of the pseudo differentiator & $\mathrm{s}$ & $w$ & Input voltage to the servo valves \\
$K_{p o s}$ & Detection sensitivity of the LVDT & $\mathrm{V} / \mathrm{m}$ & $w$ & Input voltage \\
$T_{p i}$ & Time constant of the PI compensator & $\mathrm{s}$ & $p_{d}$ & Difference of pressure in pneumatic cylinders \\
$K_{a i r}$ & Gain of the pneumatic system & $\mathrm{Va} / \mathrm{V}$ & $x$ & Position of the stage \\
$T_{a i r}$ & Time constant of the pneumatic system & $\mathrm{s}$ & $e_{M F}$ & Error between pressure signal and output of the model \\
\hline \hline
\end{tabular}




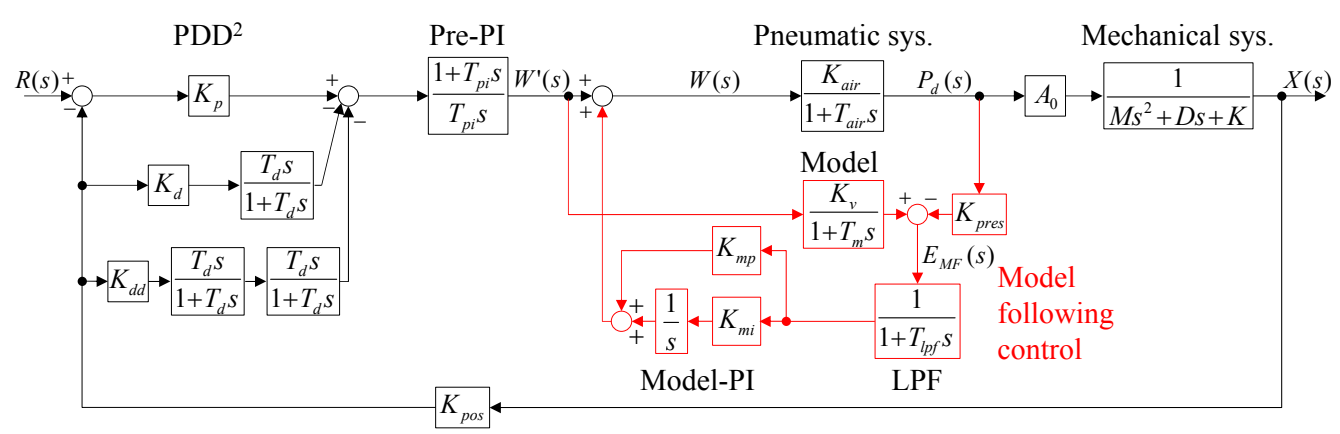

Fig.4 Control system for the pneumatic stage.

\section{3. モデルの選定と応答性改善}

\section{$3 \cdot 1$ モデルの選定}

$2 \cdot 3$ 節で既述のように, $\mathrm{PDD}^{2}$ 制御の $\mathrm{D} ・ \mathrm{D}^{2}$ 制御による岡性・粘性項の操作を可能にするため, Pre-PI との極 零相殺により空圧系を積分特性とする制御手法をとっている，そうであるならば，モデルマッチング型 2 自由 度制御系における参照モデルのように, あらかじめ積分器をモデル $P_{m}(s)$ として設定する制御構成でも実現可能 だと考えられる. 寸なわち, 図 5 に示すようにPre-PI をとり除き，積分器モデル $K_{v} / s$ を設置する. この場合な らば, Pre-PI の時定数 $T_{p i}$ の調整も不要である. 伝達関数より, 実現可能なモデルか否かを検討する. 図 5 より, 操作量 $W^{\prime}(s)$ から圧力センサ出力 $K_{\text {pres }} P_{d}(s)$ の伝達関数は,

$$
\frac{K_{\text {pres }} P_{d}(s)}{W^{\prime}(s)}=\frac{K_{v}}{s} \cdot \frac{\frac{K_{\text {air }} K_{\text {pres }}}{K_{v}} T_{l p f} s^{3}+\frac{K_{\text {air }} K_{\text {pres }}}{K_{v}} s^{2}+K_{\text {air }} K_{\text {pres }} K_{m p} s+K_{\text {air }} K_{\text {pres }} K_{m i}}{T_{\text {air }} T_{l p f} s^{3}+\left(T_{\text {air }}+T_{l p f}\right) s^{2}+\left(1+K_{\text {air }} K_{\text {pres }} K_{m p}\right) s+K_{\text {air }} K_{\text {pres }} K_{m i}}
$$

と導出される. 式(4)右辺は 2 つ要素からなる. ひとつは設計者が指定の積分器モデル $K_{v} / s$ であり, もうひと つは 3 次多項式である. 後者の分母・分子の各次数の係数が一致するとき, 極零相殺により式(4)右辺には積分 器モデル $K_{v} / s$ のみが残る. 寸なわち, 空圧系の特性は積分器となる. しかし, $s^{3}$ から $s^{1}$ の各係数はそれぞれ分 母と分子で異なっており, 調整パラメータ $K_{m p}, K_{m i}$ の值を調整しても両係数は一致しない. これでは高次項の 極零相殺がなされず，モデル追従がなされない．すなわち，積分器モデル $K_{v} / s$ の設定は不可能である.

一方で, 実システムに等しい 1 次遅れモデルの場合を考える. 式(4)と同様にして, $W^{\prime}(s)$ から $K_{\text {pres }} P_{d}(s)$ の伝達 関数を図 4 より求めると,

$$
\frac{K_{\text {pres }} P_{d}(s)}{W^{\prime}(s)}=\frac{K_{v}}{1+T_{m} s} \cdot \frac{\frac{K_{\text {air }} K_{\text {pres }}}{K_{v}} T_{m} T_{l p f} s^{3}+\frac{K_{\text {air }} K_{\text {pres }}}{K_{v}}\left(T_{m}+T_{l p f}\right) s^{2}+\frac{K_{\text {air }} K_{\text {pres }}}{K_{v}}\left(1+K_{v} K_{m p}\right) s+K_{\text {air }} K_{\text {pres }} K_{m i}}{T_{\text {air }} T_{l p f} s^{3}+\left(T_{\text {air }}+T_{l p f}\right) s^{2}+\left(1+K_{\text {air }} K_{\text {pres }} K_{m p}\right) s+K_{\text {air }} K_{\text {pres }} K_{m i}}
$$

となる. 式(4)と同様に, 右辺は 1 次遅れモデル $K_{v} /\left(1+T_{m} s\right)$ と 3 次多項式の積の形をとる. しかし，式(4)とは異 なり, 3 次多項式の $s^{3}$ から $s^{1}$ の各係数は分母と分子で同様の構造となる. ここで, $K_{v}=K_{\text {air }} K_{\text {pres }}$ かつ $T_{m}=T_{\text {air }}$ のと き，式(5)は，

$$
\frac{K_{\text {pres }} P_{d}(s)}{W^{\prime}(s)}=\frac{K_{v}}{1+T_{m} s}
$$

となり, 3 次多項式の極零相殺により空圧系の特性はモデルのそれに等しくなる. すなわち, モデル追従が有効 に機能する.

MFC という名称から，本節冒頭で述べた参照モデルに代表されるように，設計者による任意なモデルの指定 が可能だと誤認しがちである.しかし，式(4)と(5)の対比から明らかなように，モデル $P_{m}(s)$ は設計者の都合で指 定してよいのではなく, 実システムの構造に限りなく近く設定しなければモデル追従はなされない. 


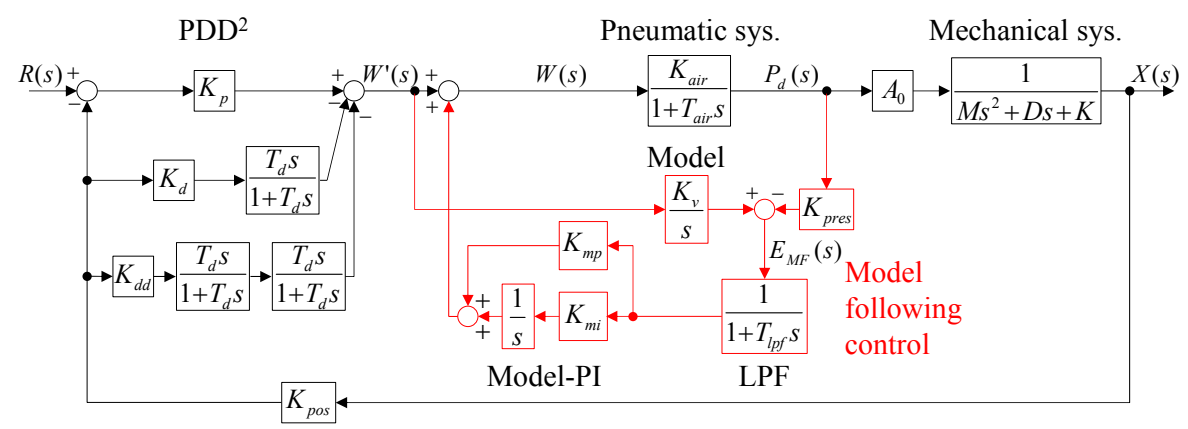

Fig. 5 Control system with integrator model.

\section{$3 \cdot 2$ 応答性改善}

3 ・1 節では，空圧系に限りなく等しくモデル $P_{m}(s)$ を指定する必要があることを示した．そのためには空圧系 の特性を明確にせね攼ならない. しかし，最小二乗法などのパラメータ推定法やサーボアナライザによる測定 において，同定誤差は避けられない，とくに，空圧系のように特性に摇らぎをもつシステムでは，これが曊著 に発現する．このような実情を踏まえ，モデルのパラメータ誤差の大小が MFC の応答性に与える影響を，極・ 零点軌跡により確認する. 式(5)右辺の 3 次多項式の極・零点配置を図 6 に示す. 固定パラメータを表 2 に示す. Model-PI の比例ゲイン $K_{m p}$ は 0.035 である. また，モデルのパラメータは $K_{v}=K_{a i r} K_{p r e s}=4.2 \times 1.4286, T_{m}=4$ と真值 に等しくしている. そのため, 図 6 ではそれぞれの極と零点は重なり, 完全に極零相殺がなされている. 以下 ではモデルのパラメータ $K_{v}$ と $T_{m}$ を変化させ，パラメータ誤差の大小が異なる 3 通りについて軌跡を確認する. ここで式(5)より，分母・分子はともに 3 次式であるため，極・零点はともに 3 つ存在する. 系の応答は原点近 傍の極 $P_{1}$ が支配的であるため，ここではこの極とそれに対応する零点 $Z_{1}$ の挙動にのみ着目する.

実適用の際には， $K_{v}$ と $T_{m}$ の誤差を Model-PI の調整により補償する. 以下では， $K_{v}$ と $T_{m}$ の真値との誤差が， (a)いずれも大きい $\left(K_{v}=0.1, T_{m}=10\right)$ ，(b) $K_{v}$ は小さく $T_{m}$ は大きい $\left(K_{v}=5.0, T_{m}=10\right)$ ，そして，(c)いずれも小さい $\left(K_{v}=5.0, T_{m}=5\right)$ 場合に，上述の調整を模擬したときの極 $P_{1}$ と零点 $Z_{1}$ の軌跡を確認する. 結果を図 7(a) (c) に それぞれ示す．比例ゲイン $K_{m p}$ を 0 から大きくしたときの軌跡である.

まず(a)の場合，零点 $Z_{1}$ は原点のごく近傍からほとんど動かない，一方で，振動成分をもつ極 $P_{1}$ は負実軸に合 流し, そのまま原点方向へ移動する. しかし, 最終的に負実軸上の原点近傍に位置する零点 $Z_{1}$ とは完全には重 ならず，極零相殺は十分になされない．次に(b)では，虚数成分を持つ極 $P_{1}$ と零点 $Z_{1}$ はともに実軸へ接近し，負 実軸上を不安定方向へ移動する，そして，最終的に両者は重なりあい，(a)よりも原点から遠い負実軸上で相殺 される，最後に(c)について，同図(b)と同様の動きであるが，こちらの方がより原点遠方において極零相殺がな されている. 以上より，モデルのゲイン $K_{v}$ および時定数 $T_{m}$ は調整パラメータのひとつであり，これらを実際の 空圧系に近い值に設定することで，代表根をより安定方向で極零相殺することができる．これは，MFCの応答 性の高速化に寄与寸る．なお，本節と後の 4 ・2 節で扱う極・零点軌跡は，実機との定量的な一致を図るもので はなく，あくまで定性的な傾向を明らかにするためのものである.

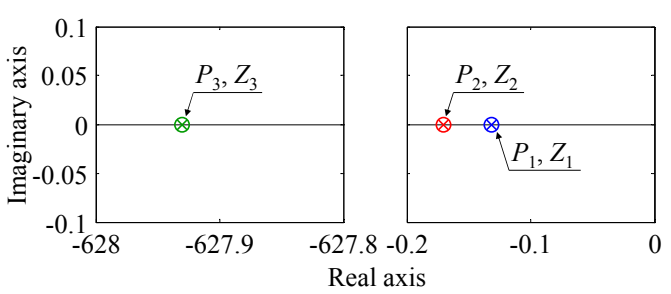

Fig. 6 Pole and zero assignment.
Table 2 Parameters used for the pole and zero loci.

\begin{tabular}{ccc}
\hline \hline Symbol & Value & Unit \\
\hline$K_{\text {air }}$ & $4.2 \times 10^{5}$ & $\mathrm{~Pa} / \mathrm{V}$ \\
$T_{\text {air }}$ & 4 & $\mathrm{~s}$ \\
$K_{\text {pres }}$ & $1.4286 \times 10^{-5}$ & $\mathrm{~V} / \mathrm{Pa}$ \\
$T_{l p f}$ & 0.0015924 & $\mathrm{~s}$ \\
$K_{m i}$ & 0.015 & $\mathrm{~V} / \mathrm{V}$ \\
\hline \hline
\end{tabular}




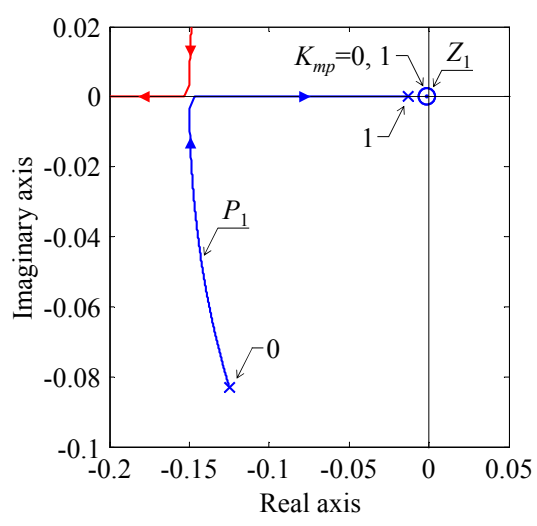

(a) $K_{v}=0.1, T_{m}=10$.

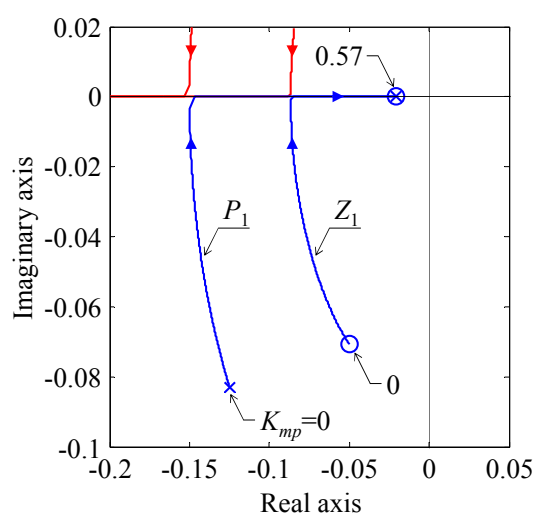

(b) $K_{v}=5.0, T_{m}=10$.

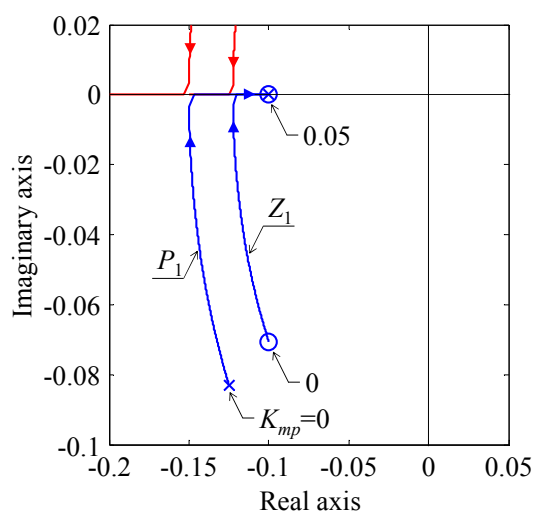

(c) $K_{v}=5.0, T_{m}=5$.

Fig. 7 Pole and zero loci in the case that $K_{v}$ and $T_{m}$ are changed. In (a), the blue pole moves near the blue zero in the neighborhood of the origin on negative real axis, but they do not fully overlap each other. (b) shows that they overlap each other on negative real axis. In (c), they overlap each other farther from origin than the case of (b).

\section{4. モデル追従制御器の改良}

\section{$4 \cdot 1$ モデル追従制御器の検討}

文献（Kato et al., 2007）では，スプール型サーボバルブの非線形特性の補償を目的として空圧式除振装置に対 して MFC を適用し，その有効性を示している，除振装置は定位浮上が目的であるため，立ち上げ時の速応性は 重要ではない, 一方, 本論文が対象とするステージは位置決め装置であるため, 応答の速さが性能の可否を決 定する. 位置決めの高速化は $\mathrm{PDD}^{2}$ 制御のゲイン調整により実現可能である. ここで, 図 4 に示寸制御系は $\mathrm{PDD}^{2}$ 制御を含むループが MFC を内包する構造である点に注意する. アウタループの高速な応答に対してインナが緩 慢であれば, 後者の効果は十分に得られない. したがって，まずインナである MFC の応答性を改善する必要が ある.これまでは文献（Kato et al., 2007）にしたがい，モデル追従制御器にはPI 補償器を使用してきた。 しか し, 同文献は空圧式除振装置を対象としており, 空圧ステージに対して同補償器が適切であるとは限らない. 以上を踏まえ，本節ではモデル追従制御器の比較・検討を行う.

$2 \cdot 3$ 節で示した PI 補償器 $C_{p i}(s)$ は,

$$
C_{p i}(s)=K_{m p}+\frac{K_{m i}}{s}
$$

と表される.ブロック図では P と I 補償器の並列接続で表現されるため, これを並列型の PI 補償器と呼称する. 並列型は, 機能が明確化された補償器ごとの投入が可能であるため, モデルフリーの制御対象に対してよく用 いられる．一方で，式(7)の並列型とは形が異なる以下の掛け算型の補償器も存在する.

$$
C_{p i}(s)=K_{m p} \cdot \frac{1+T_{m i} s}{T_{m i} s}
$$

ただし， $T_{m i}$ を積分時間とする．掛け算型では，時定数 $T_{m i}$ を制御対象の特性に対して最適值に設定すれば, これを不変のままゲイン $K_{m p}$ だけ操作できる特徵がある. そのため, 特性が一度明らかとなった制御対象に対し ては, 調整を非干渉で行える利点がある。ここで, 式(8)に示す PI 補償器において, $W(s)$ から $K_{\text {pres }} P_{d}(s)$ の伝達関 数を導出すると,

$$
\frac{K_{\text {pres }} P_{d}(s)}{W^{\prime}(s)}=\frac{K_{v}}{1+T_{m} s} \cdot \frac{\frac{K_{\text {air }} K_{\text {pres }}}{K_{v}} T_{m} T_{l p f} T_{m i} s^{3}+\frac{K_{\text {air }} K_{\text {pres }}}{K_{v}}\left(T_{m}+T_{l p f}\right) T_{m i} s^{2}+\frac{K_{a i r} K_{\text {pres }}}{K_{v}}\left(1+K_{v} K_{m p}\right) T_{m i} s+K_{\text {air }} K_{\text {pres }} K_{m p}}{T_{a i r} T_{l p f} T_{m i} s^{3}+\left(T_{a i r}+T_{l p f}\right) T_{m i} s^{2}+\left(1+K_{a i r} K_{\text {pres }} K_{m p}\right) T_{m i} s+K_{\text {air }} K_{\text {pres }} K_{m p}}
$$




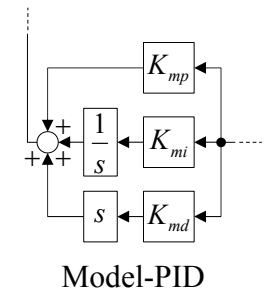

Fig. 8 Block diagram of Model-PID.

となる. 系の応答性は低次項が支配的である（北森，1998）。したがって，実際の調整過程では，低次項から高 次項方向一順に係数を合わせこむ必要がある. しかし, 式(9)右辺の 3 次多項式に着目すると， $s^{0}, s^{1}$ 項の両方に 調整パラメータの比例ゲイン $K_{m p}$ が，また $s^{1} \sim s^{3}$ 項のすべてに積分時間 $T_{m i}$ が含まれている．これでは，各項の 個別な調整，すなわち，上述の低次項から高次項方向への合わせこみができない，一方，式(7)の並列型の PI 補 償器を実装した場合, 式(5)に示すように $s^{0}$ 項に積分ゲイン $K_{m i}$ が, $s^{1}$ 項に比例ゲイン $K_{m p}$ がそれぞれ含まれる. この場合, ゲイン $K_{m i}, K_{m p}$ を順に調整することで, 低次項から係数の合わせこみが可能である. したがって, 式(7)に示す並列型の補償器の方がよい.

さらに，MFCの高速化を図るためには，モデル追従制御器のハイゲイン化が必須となる。しかし，ゲインの 増大は同時に不安定化を招く. ハイゲイン化した低次項との均衡をとるためには, 高次項の係数も同様に大き くせねばならない. しかし, 式(7)の並列型の PI 補償器では, ゲイン $K_{m i}$ と $K_{m p}$ の調整による低次項の操作しか できない，そこで，並列型の PID 補償器（以下，Model-PID と呼称）を用いた場合を式(9)と同様に検討する. Model-PID のブロック図を図 8 に示寸. 同図と図 4 より, $W(s)$ から $K_{\text {pres }} P_{d}(s)$ の伝達関数は,

$$
\frac{K_{\text {pres }} P_{d}(s)}{W^{\prime}(s)}=\frac{K_{v}}{1+T_{m} s} \cdot \frac{\frac{K_{\text {air }} K_{\text {pres }}}{K_{v}} T_{m} T_{l p f} s^{3}+\frac{K_{\text {air }} K_{\text {pres }}}{K_{v}}\left(T_{m}+T_{l p f}+K_{v} K_{m d}\right) s^{2}+\frac{K_{\text {air }} K_{\text {pres }}}{K_{v}}\left(1+K_{v} K_{m p}\right) s+K_{\text {air }} K_{\text {pres }} K_{m i}}{T_{\text {air }} T_{l p f} s^{3}+\left(T_{\text {air }}+T_{l p f}+K_{\text {air }} K_{\text {pres }} K_{m d}\right) s^{2}+\left(1+K_{\text {air }} K_{\text {pres }} K_{m p}\right) s+K_{\text {air }} K_{\text {pres }} K_{m i}}
$$

となる. 式(5)に対して式(10)では, 右辺 3 次多項式の $s^{2}$ の係数に D 補償器の微分ゲイン $K_{m d}$ が新たに含まれて いる. 寸なわち, 微分ゲイン $K_{m d}$ の調整により, さらに高次項の極零相殺ができる. これに加えて, Model-PID に $\mathrm{D}^{2}$ 補償器を並列に付加した場合, 式(10)右辺 3 次多項式の $s^{3}$ 項係数に同補償器のゲイン $K_{m d d}$ が含まれ, より 高次項の相殺が可能となる.

\section{$4 \cdot 2$ D 補償器による極零相殺}

$4 \cdot 1$ 節で導入した微分ゲイン $K_{m d}$ の調整効果を, 極・零点軌跡を使って明らかにする. まず, 圧力センサの 高周波ノイズ除去のために設置している Model-PID 前段の LPF は, 簡単化のため取り除く. すると, 伝達関数 は式(10)において， $T_{p p f}=0$ とすればよい，このとき高次の $s^{3}$ 項が消えるが，応答に与える影響は微小であるため 問題ない. $4 \cdot 1$ 節で既述のように低次項が応答性を支配するという原則にしたがい，低次項から高次項方向一 順に係数を合わせこむ. 本解析でも，この調整方法を踏襲し，調整過程の極・零点の軌跡を確認する. 式(10) においては, 低次項から順に調整ゲイン $K_{m i}, K_{m p}, K_{m d}$ が各次数の項に含まれているため, この順に調整する必 要がある.まず, 積分ゲイン $K_{m i}$ を 0 から大きくしたときの極・零点軌跡を図 9(a)に示す. なお，比例ゲイン $K_{m p}$ および微分ゲイン $K_{m d}$ は 0 に固定している. 同図より，負実軸上に配置された $2 つ の$ 極は，互いに接近した 後に虚軸と並行に分岐し, 複素根となる. 零点も同様の動きをとる. 次に, $K_{m i}=10$ で固定し, 比例ゲイン $K_{m p}$ を変化させる. 図 9(b)より, 安定領域を始点とする複素根と零点は, 負実軸上で合流し, 一対の極 $P_{1}$ と零点 $Z_{1}$ は原点方向へ, もう一対の $P_{2}$ と $Z_{2}$ は安定方向一向かう. 原点近傍の極 $P_{1}$ と零点 $Z_{1}$ は不安定方向に移動するが 徐々に接近し, やがて負実軸上でほぼ重なる.一方で, もう一対の $P_{2}$ と $Z_{2}$ は安定方向に向からが互いに離れる. すなわち, 原点近傍の極・零点の相殺はなされるが, もう一方はなされない. 最後に, 図 $9(\mathrm{c})$ に示すように $K_{m}=10$, $K_{m p}=30$ で固定し, 微分ゲイン $K_{m d}$ に值を入れていく. 原点遠方の極 $P_{2}$ と零点 $Z_{2}$ は, 距離を縮めながら負実軸上 を原点方向へ移動する. 最終的に, 両者は原点近傍でほぼ重なり, 極零相殺がなされる. 一方で原点近傍を始 


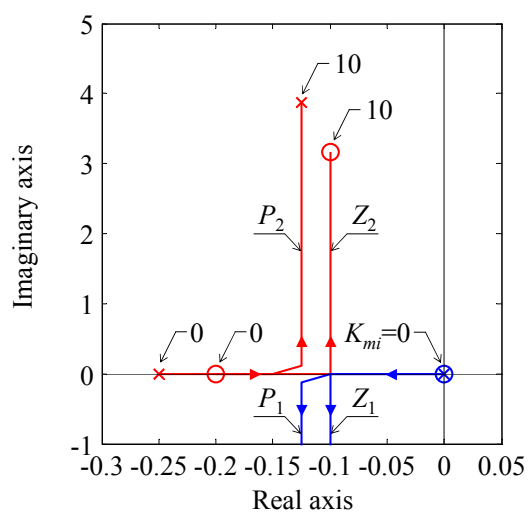

(a) Changing the gain $K_{m i}$.

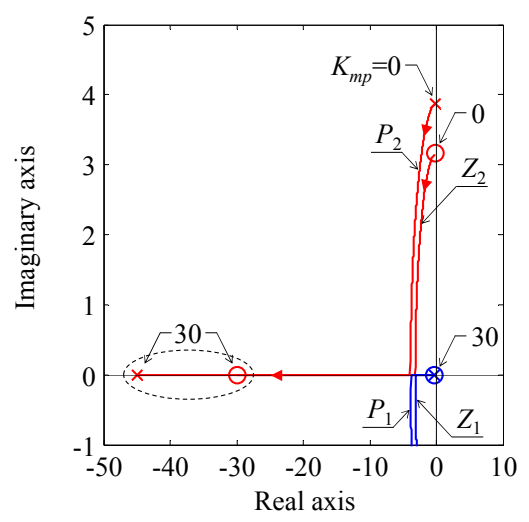

(b) Changing the gain $K_{m p}$.

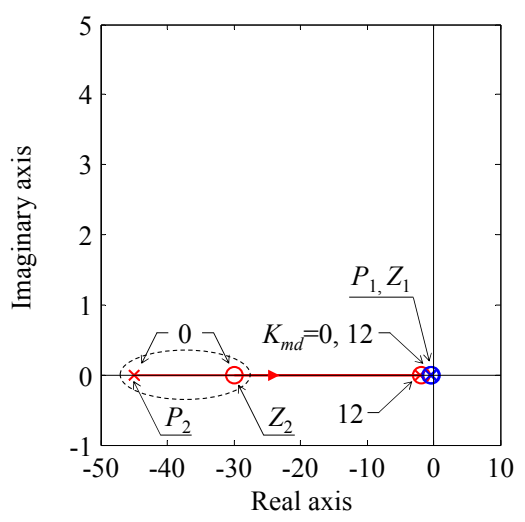

(c) Changing the gain $K_{m d}$.

Fig. 9 Pole and zero loci with the gain $K_{m i}, K_{m p}$ and $K_{m d}$ changing. (a) shows that two pairs of pole and zero move parallel with imaginary axis from negative real axis. In (b), two pairs of pole and zero move back to real axis. One pair runs in the neighborhood of the origin with pole-zero cancelation, and another pair goes to opposite direction without cancelation. In (c), the pair without cancelation moves to the origin and finally overlaps at the left side of the pair with pole-zero cancelation.

点とする極 $P_{1}$ と零点 $Z_{1}$ は，互いに重なった状態を保持したまま，原点から遠ざかる方向へ実軸上を微動する. つまり，D補償器の導入により，PI 補償器だけでは実現不可能な極・零点の相殺が可能になる.

\section{5. 実機実験}

\section{$5 \cdot 1$ モデルの調整と効果}

$3 \cdot 2$ 節では, 1 次遅れモデルのゲイン $K_{v}$ および時定数 $T_{m}$ を調整パラメータとして扱い, これらを実システム の值に近づけることで応答が高速化することを極・零点軌跡により定性的に確認した．従来研究では，サーボ アナライザによる正弦波加振で得た周波数応答から，空圧系のゲイン $K_{\text {air }}$ と時定数 $T_{\text {air }}$ の概算值を算出し，これ をもとに $K_{v}=0.1 ， T_{m}=10 \mathrm{~s}$ を使用していた（Ito et al., 2016）。しかし，対象とするステージは転がり軸受で案内さ れ摺動部に非線形摩擦を有するため，入力振幅依存性をもつ. そのため，アナライザの測定結果にはパラメー 夕誤差を含む.したがって，これら 2 值は再調整の余地がある.そこで，実機による調整を行った。具体的に は， $K_{v}$ あるいは $T_{m}$ を変化させながら位置決めをし，そのときの偏差 $e_{M F}(t)$ の時間応答を観測した．結果を図 10 に示す. 同図より， $K_{v}$ あるいは $T_{m}$ を変化させると，位置決め直後の時刻 $4 \mathrm{~s}$ の振れ幅に差異が生じている. こ れは，以下に示す入力電圧 $W^{\prime}(s)$ から偏差 $E_{M F}(s)$ の伝達関数により説明できる.

$$
\frac{E_{M F}(s)}{W^{\prime}(s)}=\frac{\frac{K_{v}}{1+T_{m} s}-\frac{K_{a i r} K_{p r e s}}{1+T_{a i r} s}}{1+\frac{K_{a i r} K_{p r e s}}{1+T_{a i r} s} \frac{1}{1+T_{l p f} s}\left(K_{m p}+\frac{K_{m i}}{s}\right)}
$$

式(11)右辺の分子に着目して，第 1 項は設定したモデル，第 2 項は空圧系である. 同式より，調整によりモデ ルを空圧系に近づけると, 偏差 $E_{M F}(s)$ が小さくなる.これと図 10 より, 振れ幅が最小である $K_{v}=5.0, T_{m}=5 \mathrm{~s}$ を, 実際の空圧系の值により近いものとして選択した。 なお，調整は $T_{m}=10$ として $K_{v}$ から行い，次に $K_{v}=5.0$ で固定 して $T_{m}$ の調整をしている。また，同図に示す傾向はシミュレーションにおいても同様に得られたが，紙面の都 合上ここでは割愛する.

次に，モデルの調整が応答性に与える効果を実機により確認する. 位置決め時の偏差 $e_{M F}(t)$ の時間応答を， $K_{v}$ と $T_{m}$ の調整前後で比較した結果を図 11 に示す. $50 \mathrm{~s}$ 程度の収束時間が，調整によりおよそ $30 \mathrm{~s} に$ 短縮されてい る.これは図 7 に示す結果，すなわち，極の左半面移動に伴う応答の高速化に合致する. 


\section{5・2 Model-PID の効果}

$5 ・ 1$ 節の $K_{v}$ と $T_{m}$ の調整結果で得られた值を使用して，ここでは Model-PID を実機に実装したときの効果を 確認する. 位置決め時における偏差 $e_{M F}(t)$ の時間応答を, Model-PID の D 補償器の有無で比較した。実験結果を 図 12 に示す. D 補償器の適用により，振れ幅が小さくなり，過渡特性が改善されている. なお，微分兮イン $K_{m d}$ は，実験により試行錯誤的に得た值を使用している，なお，実装に際して完全微分器ではなく，時定数 $5 \mathrm{~s}$ の擬 似微分器を使用した.

\section{$5 \cdot 3$ 繰り返し位置決め}

$5 \cdot 1,5 \cdot 2$ 節ではモデルパラメータ $K_{v}$ と $T_{m}$ の調整と Model-PID への変更をそれぞれ行い，MFCの応答性改 善を確認した。ここでは，繰り返し位置決めにより，上記手法の有効性を実機検証する． $K_{v}$ と $T_{m}$ の調整前，調 整後，さらに Model-PID 使用時のそれぞれで 5 回連続の位置決めを行い，定常状態のばらつきを比較した。結 果を図 13 に示す. $K_{v}$ と $T_{m}$ の調整により，85 $\mu \mathrm{m}$ のばらつきが $40 \mu \mathrm{m}$ 程度に減少した. さらに, Model-PIから PID に変更することで，およそ $30 \mu \mathrm{m}$ の範囲に減少している．また，過渡応答に関して，図 13 中段では上段よ りも整定時間が遅くなっていることが時間軸に直交する破線より確認できる。これは，5・1 節で実施したモデ ルのパラメータ調整により, 時定数 $T_{m}$ を $10 \mathrm{~s}$ から $5 \mathrm{~s}$ に変更したためである. すなわち, 時定数が小さくなり, 立ち上がりが高速化することでオーバシュートが生じたためである。しかし，同図下段では中段よりも整定が 速くなっている. D 補償器の追加により，図 12 のように過渡応答が良化したためである. 最終的に，上段と下 段を比較すると，整定時間は同じであり過渡特性の悪化はない. 以上より，提案法の有効性を確認できた.
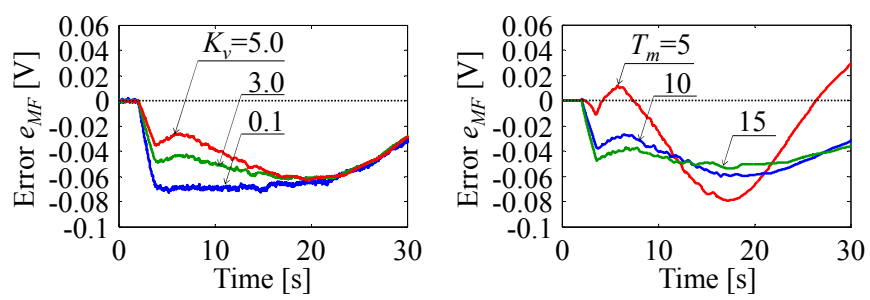

Fig. 10 Tuning of $K_{v}$ and $T_{m}$. Left and right figures show the tuning result of $K_{v}$ and that of $T_{m}$, respectively. In case of $K_{v}=5.0$, since the amplitude just after stage positioning, i.e. at about $4 \mathrm{~s}$, is minimal, this value is selected as closer one to the gain of pneumatic system. In the same way, $T_{m}=5$ is selected.

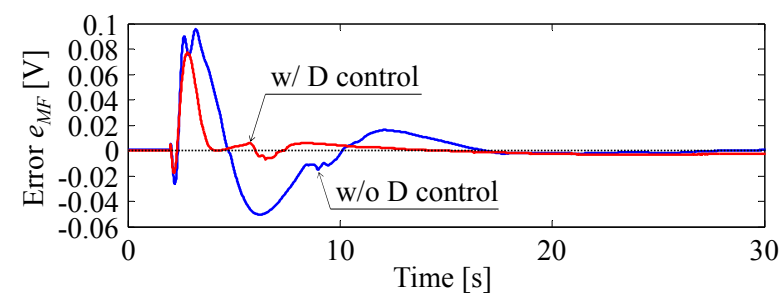

Fig. 12 The effect of Model-PID. Settling time of error $e_{M F}(t)$ is reduced by using a PID controller as the model following controller instead of a PI.

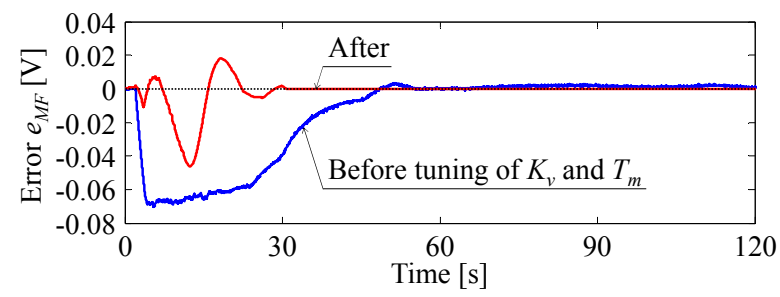

Fig. 11 The effect of tuning of $K_{v}$ and $T_{m}$. Settling time of error $e_{M F}(t)$ is reduced by tuning of $K_{v}$ and $T_{m}$.

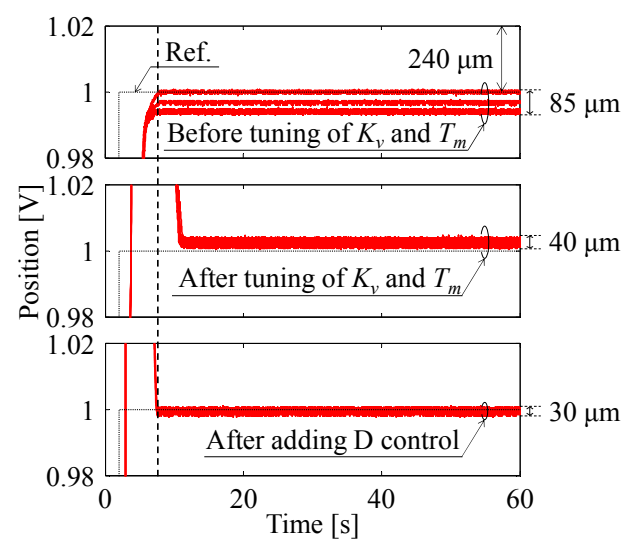

Fig. 13 Results of repetitive positioning experiments. Each figure shows the result of 5 times repeat positioning. Compared to before tuning of $K_{v}$ and $T_{m}$, repeat positioning accuracy improves after tuning of them. Moreover, it improves more by adding a D control to the model-PI. 


\section{6. 結}

本論文の結論は以下の通りである.

(1) MFC におけるモデルは，モデルマッチング型 2 自由度制御系における参照モデルのように任意に指定がで きない．実システムの伝達関数の構造を把握した上で，かつパラメータを真值に限りなく近く設定しなけ ればモデル追従は十分なされない，近づけるほどMFC の応答は高速化する.

（2）そのためには実システムの正確な同定を要するが，実際には同定誤差は不可避である．同誤差を補償する モデル追従制御器には，部分的モデルマッチングの観点から，PI より PID 補償器の方が高周波領域の調整 ができる点で優位である，後者を実装し，MFC の過渡応答の改善を実験的に確認した。

(3) 繰り返し位置決めによりステージ位置の定常值のばらつきを評価し，パラメータ調整後のモデルおよび Model-PID の有効性を実験的に示した.

\section{文献}

藤田壽憲, 小島英介, 田島正之, 宮島隆至, 榊和敏, 川嶋健嗣, 香川利春, サーボ弁の動特性を考慮した空気圧サ 一ボシステムの制御系設計，日本機械学会年次大会講演論文集, Vol.2, No.2 (2006), pp.309-310.

藤原篤, 勝間田浩一, 石田義久, 能登山俊一, 外乱オブザーバを併用した空気圧シリンダの最適制御, 油圧と空気 圧, Vol.27, No.6 (1996), pp.796-802.

橋本強二, 今枝正夫, 小西克信, 菊輪好太郎, 空気圧シリンダの適応的位置決め制御, 油圧と空気圧, Vol.22, No.2 (1991), pp.162-168.

Ito, N., Wakui, S. and Nakamura, Y., Pneumatic stage positioning with model following control and PDD $^{2}$ control, International Journal of Advanced Mechatronic Systems, Vol.6, No.6 (2016), pp.247-257.

Kato, T., Kawashima, K. and Kagawa, T., Active control of a pneumatic isolation table using model following control and a pressure differentiator, Precision Engineering, Vol.31, No.3 (2007), pp.269-275.

北森俊行, I-PD 制御方式の原理と設計法，システム/制御情報：システム制御情報学会誌，Vol.42，No.1 (1998), pp.7-17.

則次俊郎，福薗康介，高岩昌弘，ファジイ制御を用いた空気圧サーボ系の動特性改善，油圧と空気圧，Vol.25, No.6 (1994), pp.733-738.

Parnichkun, M. and Ngaecharoenkul, C., Kinematics control of a pneumatic system by hybrid fuzzy PID, Mechatronics, Vol.11, Issue8 (2001), pp.1001-1023.

三東佳史樹，涌井伸二，空圧ステージに対する簡易なデュアル外乱オブザーバの実装，日本機械学会論文集 C 編， Vol.79, No.799 (2013), pp.738-742.

田中秀幸, 杉江俊治, 片山徹, 2 自由度系を用いた構造系と制御系の同時設計，計測自動制御学会論文集，Vol.35， No.12 (1999), pp.264-269.

柳川敦志, 涌井伸二, 空圧ステージへの流量外乱オブザーバ付き完全 2 自由度 $\mathrm{PDD}^{2}$ 制御の適用, 日本機械学会論 文集 C 編, Vol.76, No.766 (2010), pp.1496-1502.

\section{References}

Fujita, T., Kojima, E., Tajima, M., Miyajima, T., Sakaki, K., Kawashima, K. and Kagawa, T., Control system design of pneumatic servo system considering dynamic characteristics of servo valve, JSME annual meeting, Vol.2, No.2 (2006), pp.309-310 (in Japanese).

Fujiwara, A., Katsumata, K., Ishida, Y. and Notoyama, S., An optimal control for pneumatic cylinder with disturbance observer, Journal of the Japan Hydraulics \& Pneumatic Society, Vol.27, No.6 (1996), pp.796-802 (in Japanese).

Hashimoto, K., Imaeda, M., Konishi, K. and Kikuwa, K., Adaptive position control of a pneumatic cylinder, Journal of the Japan Hydraulics \& Pneumatic Society, Vol.22, No.2 (1991), pp.162-168 (in Japanese).

Ito, N., Wakui, S. and Nakamura, Y., Pneumatic stage positioning with model following control and $\mathrm{PDD}^{2}$ control, International Journal of Advanced Mechatronic Systems, Vol.6, No.6 (2016), pp.247-257.

Kato, T., Kawashima, K. and Kagawa, T., Active control of a pneumatic isolation table using model following control and a pressure differentiator, Precision Engineering Vol. 31, No. 3 (2007), pp. 269-275.

Kitamori, T., Peinciple, synthesis and design of I-PD control, Transaction of the Institute of Systems, Control and Information 
Engineers, Vol.42, No.1 (1998), pp.7-17 (in Japanese).

Noritsugu, T., Fukuzono, K. and Takaiwa, M., Improvement of dynamic characteristics of pneumatic servo system with fuzzy control, Journal of the Japan Hydraulics \& Pneumatic Society, Vol.25, No.6 (1994), pp.733-738 (in Japanese).

Parnichkun, M. and Ngaecharoenkul, C., Kinematics control of a pneumatic system by hybrid fuzzy PID, Mechatronics, Vol.11, Issue8 (2001), pp.1001-1023.

Santo, Y. and Wakui, S., Implementation of an easy dual disturbance observer for pneumatic stages, Transactions of the Japan Society of Mechanical Engineers, Series C, Vol.79, No.799 (2013), pp.738-742 (in Japanese).

Tanaka, H., Sugie, T. and Katayama, T., Simultaneous design of structure and control system using two-degree-of -freedom-controller, Transactions of the Society of the Instrument and Control Engineers, Vol.35, No.12 (1999), pp.264-269 (in Japanese).

Yanagawa, A. and Wakui, S., Application of perfect 2 DOF PDD $^{2}$ control with flow disturbance observer for a pneumatic stage, Transactions of the Japan Society of Mechanical Engineers, Series C, Vol.76, No.766 (2010), pp.1496-1502 (in Japanese). 